\title{
PENINGKATAN KEPUASAN MAHASISWA MELALUI KUALITAS JASA PENDIDIKAN : Studi pada Mahasiswa di STIE Indonesia Banking School
}

\author{
Wasi Bagasworo 4 \\ Santi Rimadias ${ }^{5}$
}

\begin{abstract}
This research discusses about the service quality through service performance affect customer satisfaction at STIE Indonesia Banking School (IBS). In this study, the variable of the service performance is measured through three dimensions: interaction quality, environmental quality and quality of results. Each of these dimensions will be partially tested how it affects customer satisfaction. In addition, this study also wanted to know which the most influential dimension to customer satisfaction. The research sample was 214 students who studied at least one year in STIE Indonesia Banking School. The observations will be analyzed using the Statistical Product and Service Solutions (SPSS). The results from the study showed that the three dimension of service performance have a strong significant effect on customer satisfaction.
\end{abstract}

Keywords: Service Performance, Interaction Quality, Environmental Quality and Quality of Results, and Customer Satisfaction.

\section{PENDAHULUAN}

\subsection{Latar Belakang Masalah}

Masuknya Indonesia dalam Masyarakat Ekonomi Asean (MEA) yang akan dilaksanakan pada tahun 2015 menyebabkan persaingan antara perguruan tinggi di wilayah Asean semakin ketat. Hal ini didukung oleh posisi Indonesia dari hasil survey Human Development Index (HDI), Indonesia pada tahun 2012 menempati peringkat 121 dari 186 negara di dunia (sindonews.com). Walaupun STIE Indonesia Banking School merupakan sekolah tinggi yang memfokuskan diri di bidang perbankan namun masih rentan terhadap persaingan dari perguruan tinggi di Asean seperti dari Singapura dan Malaysia yang secara umum memiliki kualitas yang lebih baik. Persaingan yang ketat sesama perguruan tinggi di wilayah Asean mengharuskan STIE IBS untuk terus meningkatkan kualitas jasa pendidikan kepada mahasiswa sehingga kepuasan konsumen akan terus terjaga. 
Kepuasan mahasiswa merupakan hal yang penting dalam memastikan apakah perguruan tinggi mencapai tujuan mereka (Bryant, 2006; Ozgungor, 2010 dalam Tessema, Ready dan Yu, 2012). Selanjutnya Gerson (1993) mengemukakan "when a product or service meets or exceeds a customer's expectations, the customer is ussually satisfied." Merujuk pada apa yang dikemukakan oleh Gerson (1993) maka institusi perguruan tinggi dalam hal ini harus berupaya memperoleh kepuasan mahasiswa dengan membangun kualitas jasa yang sesuai atau melampaui harapan mahasiswa.

Berdasarkan hal tersebut, peneliti ingin melihat pengaruh kualitas jasa pendidikan yang diberikan kepada STIE IBS kepada mahasiswa melalui metode penilaian kuantitatif yang standar untuk pelayanan jasa yaitu metode SERVPERF (Service Performance) yang meliputi faktor-faktor kualitas interaksi, kualitas lingkungan fisik dari jasa, dan kualitas hasil yang berdampak terhadap kepuasan mahasiswa. Penelitian ini berjudul "Peningkatan Kepuasan Mahasiswa Melalui Kualitas Jasa Pendidikan : Studi pada Mahasiswa di STIE Indonesia Banking School “

\subsection{Perumusan Masalah}

Berdasarkan latar belakang tersebut, adapun permasalahan dalam penelitian ini adalah:

1. Adakah pengaruh kualitas jasa interaksi terhadap kepuasan mahasiswa S1 di STIE Indonesia Banking School ?

2. Adakah pengaruh kualitas lingkungan jasa terhadap kepuasan mahasiswa S1 di STIE Indonesia Banking School ?

3. Adakah pengaruh kualitas hasil terhadap kepuasan mahasiswa S1 di STIE Indonesia Banking School?

4. Pengaruh manakah yang paling dominan diantara pengaruh kualitas jasa interaksi, lingkungan jasa dan hasil terhadap kepuasan mahasiswa S1 di STIE Indonesia Banking School?

\subsection{Tujuan dan Manfaat}

Tujuan dari penelitian kepuasan pelanggan mahasiswa angkatan 2010 - 2012 terhadap pelayanan di STIE Indonesia Banking School adalah:

1. Mengetahui dan menganalisis pengaruh kualitas jasa interaksi terhadap kepuasan mahasiswa S1 di STIE Indonesia Banking School ?

2. Mengetahui dan menganalisis pengaruh kualitas lingkungan jasa terhadap kepuasan mahasiswa S1 di STIE Indonesia Banking School ?

3. Mengetahui dan menganalisis pengaruh kualitas hasil terhadap kepuasan mahasiswa S1 di STIE Indonesia Banking School?

4. Mengetahui dan menganalisis pengaruh yang paling dominan diantara pengaruh kualitas jasa interaksi, lingkungan jasa dan hasil terhadap kepuasan mahasiswa S1 di STIE Indonesia Banking School?

Manfaat dari penelitian Pengaruh Kualitas Jasa Pendidikan PTS terhadap kepuasan mahasiswa S1 di STIE Indonesia Banking School adalah membantu pengambil keputusan di STIE Indonesia Banking School untuk membuat kebijakan-kebijakan dalam peningkatan kualitas jasa pendidikan sehingga dapat meningkatkan kepuasan mahasiswa di STIE Indonesia Banking School. 


\section{TINJAUAN TEORITIS}

\subsection{Perilaku Konsumen}

Perilaku konsumen dapat dipelajari dengan cara dua pendekatan, yakni pendekatan manajerial dan pendekatan holistik (Assael, 2001). Pendekatan manajerial cenderung bersifat mikro dan kognitif. Sifat mikro terjadi karena pemahaman perilaku konsumen dilakukan secara individual berdasarkan sikap, persepsi, gaya hidup dan karakteristik demografi. Sifat kognitif terjadi karena menekankan proses pemikiran konsumen individual dan faktor yang mempengaruhi keputusan konsumen. Pendekatan holistik berorientasi makro karena cenderung terfokus kepada sifat pengalaman konsumsi daripada proses pembelian.

\subsection{Kualitas Produk}

Kualitas produk menurut Kotler dan Armstrong (2006) adalah kemampuan dari suatu produk untuk menjalankan fungsinya meliputi ketahanan, kehandalan, ketepatan, kemudahan dalam penggunaan dan perbaikan, dan nilai atribut lainnya dalam sebuah produk.

Levitt (1986) dalam Wijaya (2012) mengajukan konsep total produk, di mana jasa yang ditawarkan meliputi produk inti/generik, produk yang diharapkan (expected product), produk tambahan (augmented product), dan produk potensial. Produk dapat meliputi produk tunggal, perpaduan produk, gabungan produk barang dan jasa, atau beberapa produk barang dan jasa terkait lainnya.

\subsection{Produk Jasa Pendidikan}

Menurut Kotler \& Armstrong (2010), produk jasa pendidikan merupakan penawaran jasa pendidikan yang ditawarkan sekolah secara normal meliputi aktifitas pembelajaran dan jasa pendidikan lainnya. Produk jasa pendidikan kemudian dapat diperinci lagi menjadi :

1. Rentang produk, yaitu aneka produk jasa pendidikan yang ditawarkan.

2. Manfaat produk, yaitu manfaat aktifitas pembelajaran bagi mahasiswa dan apakah produk jasa pendidikan berorientasi pada konsumen atau produsen jasa pendidikan.

3. Usia produk, yaitu lama waktu berlangsungnya proses pembelajaran.

4. Kualitas produk, yaitu apakah produk jasa pendidikan memenuhi persyaratan kualitas yang diinginkan pelangggan jasa pendidikan.

Lockhart (2005) juga mengatakan bahwa produk jasa pendidikan adalah produk, jasa, atau atribut sekolah apapun yang menyediakan manfaat bagi konsumen jasa pendidikan, baik internal maupun eksternal.

Lovelock dan Whirtz (2011) juga memiliki pendapat bahwa produk jasa terdiri atas dua unsur penting, yaitu:

1. Produk inti, yang ditujukan pada manfaat dasar yang diterima konsumen.

2. Jasa pelengkap, yang dapat membantu membedakan produk inti dan menciptakan keunggulan kompetitif.

Lovelock dan Whirtz (2011) mengatakan ada delapan atribut jasa yang membungkus produk sebagai intinya. Delapan atribut jasa disebut juga sebagai bunga jasa (the flower of service). Pemasar jasa harus memastikan bahwa setiap unsur jasa harus tampil prima dan saling mendukung. 


\subsection{Service Performance (SERVPERF)}

Service performance adalah kinerja dari pelayanan yang diterima oleh konsumen itu sendiri dan menilai kualitas dari pelayanan yang benar-benar mereka rasakan (Cronin dan Taylor, 1994). Dari sekian peneliti yang tidak sependapat dengan Parasuraman, Zeithaml, dan Berry adalah Cronin dan Taylor $(1992,1994)$ yang menyatakan bahwa pengukuran kualitas jasa seperti yang diajukan model SERVQUAL telah menimbulkan kebingungan dan memiliki dua arti. Penulis ini menyatakan bahwa ukuran yang berdasarkan kinerja akan lebih merefleksikan kualitas jasa/pelayanan. Skala SERVPERF dinyatakan lebih tepat dalam mengukur kualitas jasa (Teas, 1994), karena skala SERVQUAL yang menggunakan perbandingan persepsi dan harapan untuk mengukur kualitas jasa, mendefinisikan konsep kualitas jasa yang diterima dihubungkan dengan konsepsi (persepsi-harapan). Dalam model Brady dan Cronin (2001), kualitas jasa terdiri atas tiga komponen utama, yaitu kualitas interaksi, kualitas lingkungan fisik, dan kualitas hasil. Masingmasing komponen kemudian dijabarkan lagi ke dalam sub komponen sebagaimana tersaji dalam gambar berikut ini:

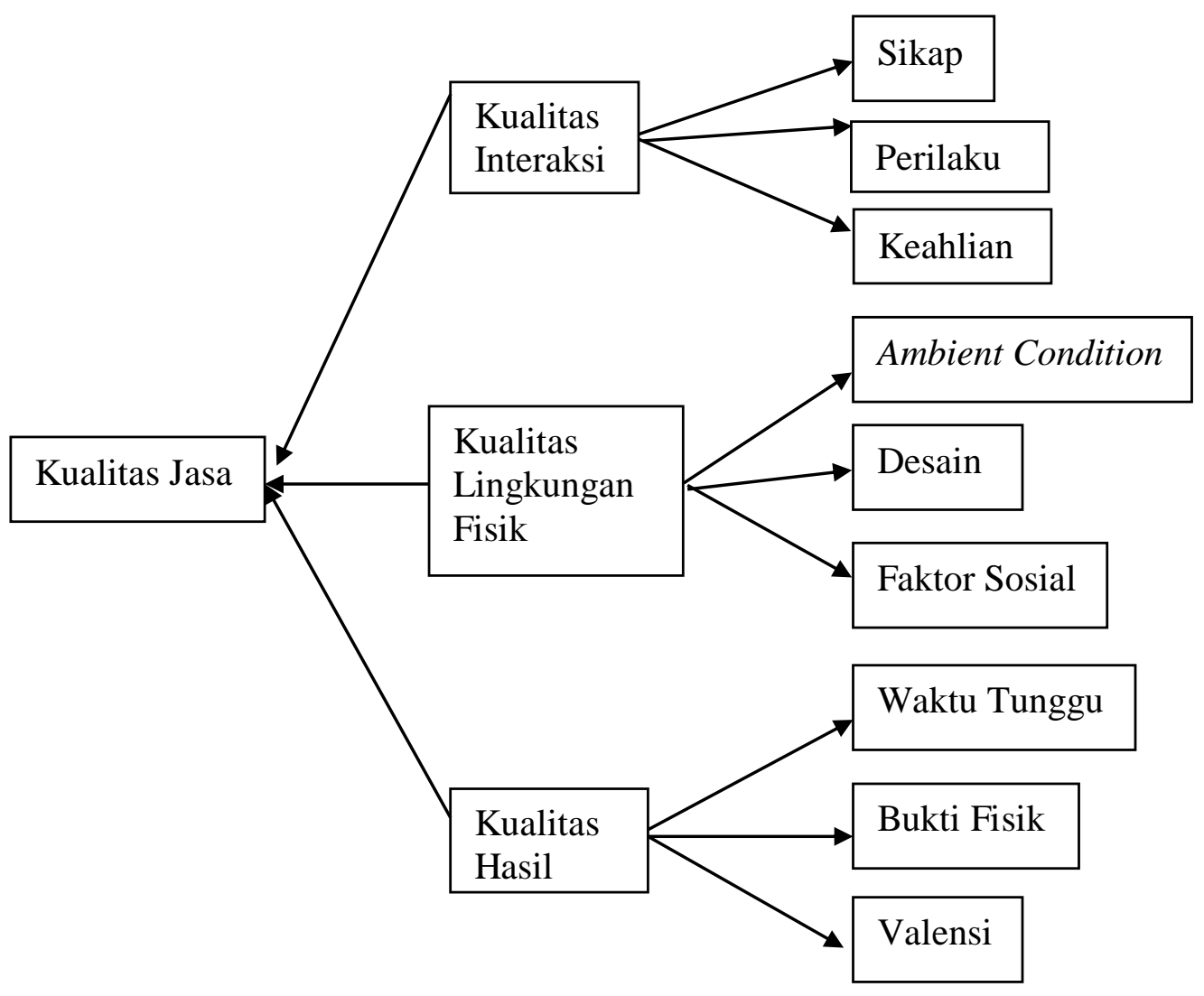

Gambar 2.2. Model Dimensi SERVPERF

Sumber : Brady dan Cronin (2001)

Model tersebut di atas merupakan model di dalam menentukan aspek kualitas layanan yang sesuai dengan bentuk-bentuk konformansi teori model yang mengindikasikan bahwa kualitas interaksi dalam berbagai bentuknya intinya mengarahkan kepada bagaimana 
memberikan suatu bentuk layanan yang sesuai dengan sikap, perilaku dan keahlian yang dimiliki oleh para pengembang layanan jasa agar pihak yang mendapatkan layanan merasakan kualitas jasa. Selanjutnya bahwa untuk mengembangkan kualitas lingkungan fisik yang memengaruhi kualitas jasa, maka kondisi ambient, desain dan faktor sosial tidak dapat diabaikan. Apabila ketiga hal tersebut terpenuhi, maka secara langsung atau tidak langsung pihak layanan jasa akan memberikan apresiasi tentang kualitas jasa yang diterimanya.

Kualitas hasil juga ditentukan oleh adanya kondisi pemberian layanan berdasarkan waktu tunggu, bukti fisik dan valensi dari segala bentuk kegiatan layanan yang fokusnya merupakan hasil dari kualitas layanan yang diharapkan mampu memberikan kontribusi besar terhadap kualitas layanan.

\subsubsection{Kualitas Interaksi}

Gronroos (2007) menyatakan bahwa kualitas interaksi yaitu kualitas yang berhubungan erat dengan bagaimana proses interaksi karyawan penyedia layanan terhadap konsumennya. Proses interkasi tersebut dapat dilihat bagaimana cara karyawan bersikap, berperilaku terhadap konsumen serta keahlian yang mereka miliki. Kualitas interaksi digambarkan dalam tiga dimensi yaitu :

a. Sikap yaitu kepribadian yang dimiliki oleh karyawan yang menunjukkan keramahan terhadap konsumen.

b. Perilaku disini dimaksudkan dengan sifat yang baik dari karyawan serta kemauan untuk melayani.

c. Keahlian yaitu kemampuan staf dalam melaksanakan pekerjaannya.

\subsubsection{Kualitas Lingkungan Fisik}

Kualitas lingkungan fisik menurut Gronroos (2007) adalah sebuah kualitas yang ada di dalam lingkungan dimana proses pelayanan itu terjadi. Dan menurut Brady dan Cronin (2001) kualitas lingkungan fisik ini digambarkan dalam tiga subdimensi yaitu:

a. Kondisi lingkungan (ambient condition) yaitu suatu kondisi yang dapat memberikan kenyamanan yang berkenaan dengan aspek nonvisual.

b. Desain yaitu berhubungan dengan tata letak atau arsitektur ruangan.

c. Faktor sosial yaitu jumlah dan tipe konsumen yang berada dalam lingkungan pelayanan, seperti tentang perilaku mereka.

\subsubsection{Kualitas Hasil}

Brady dan Cronin (2001) mendenfinisikan hasil yang diperoleh oleh konsumen ketika proses produksi (jasa) selesai dilakukan. Dan kualitas hasil digambarkan dalam tiga subdimensi yaitu :

a. Waktu tunggu yaitu waktu yang konsumen gunakan untuk untuk menunggu kualitas yang didapat.

b. Bentuk nyata yaitu segala sesuatu yang berwujud

c. Valensi yaitu ukuran tentang pengalaman yang didapat bisa baik ataupun jelek. 


\subsection{Kepuasan Konsumen}

Menurut Oliver (2003) yang dikutip oleh Lovelock dan Wirtz (2011), customer satisfaction adalah evaluasi purna beli, dimana persepsi terhadap kinerja alternatif produk/jasa yang dipilih memenuhi atau melebihi harapan sebelum pembelian. Sedangkan menurut Lovelock dan Wirtz (2011), kepuasan konsumen adalah perasaan konsumen entah itu puas atau tidak yang merupakan dampak dari pengalaman konsumsi ketika membandingkan antara pelayanan yang diterima atau barang yang didapat dengan ekspektasi konsumen tersebut.

Zeithaml, et al (2008) mendefinisikan kepuasan sebagai evaluasi konsumen terhadap barang atau jasa dalam hubungannya dengan apakah barang atau jasa tersebut dapat memenuhi kebutuhan dan harapanya. Kepuasan dapat juga diasosiasikan dengan perasaan senang (pleasure) terhadap jasa. Sedangkan Kotler dan Amstrong (2010) mendefinisikan kepuasan konsumen sebagai "The extent to which product's perceived performance matches a buyer's expectations", dapat diartikan bahwa kepuasan konsumen adalah tingkatan dimana kinerja produk yang dirasakan memenuhi harapan pembeli jika kinerja produk dibawah harapan, konsumen merasa tidak puas. Jika kinerja melebihi harapan, konsumen mendapatkan kepuasan yang tinggi atau sangat senang (delight).

Menurut Kotler (2010) kepuasan konsumen adalah dilihat dari sejauh mana kinerja suatu produk yang dirasakan cocok dengan harapan pembeli sehingga dapat menimbulkan perasaan senang atau kecewa pada seorang pembeli. Pengalaman menggunakan pengetahuan tentang tingkatan suatu produk atau layanan merupakan faktor penentu yang penting bagi konsumen dalam menilai kinerja layanan. Boone dan Kurtz (2007) mengartikan kepuasan konsumen sebagai hasil dari barang atau jasa yang memenuhi atau melebihi kebutuhan dan harapan pembeli.

Menurut Hassan,et al (2009) kepuasan konsumen dapat diukur melalui :

1. Pelayanan yang diterima

2. Pengalaman yang memuaskan

3. Penyedia layanan

4. Pilihan dalam menggunakan pelayanan

5. Secara keseluruhan, puas dengan pelayanan yang diterima

\subsection{Rerangka Pemikiran}

\subsubsection{Hubungan Kualitas Interaksi dengan Kepuasan Konsumen}

Pembentukan hipotesis dimana kualitas interaksi berpengaruh siginifikan terhadap kepuasan konsumen ditentukan oleh penelitian yang dilakukan oleh Mansor et al (2012) menyatakan bahwa kualitas interaksi merupakan pengalaman konsumen terhadap karyawan (dosen dan karyawan untuk di kampus) yang telah memberikan pelayanan terbaik. Kualitas interaksi menjadi salah satu faktor paling penting yang mempengaruhi kepuasan konsumen. Kemudian Gronroos (2007) juga mengatakan bahwa kualitas interaksi merupakan kualitas yang berhubungan erat dengan bagaimana proses interaksi karyawan penyedia layanan terhadap konsumennya. Hal ini dapat dimaknai bahwa kualitas interaksi berpengaruh positif terhadap kepuasan konsumen.Ini menjadi dasar pengembangan hipotesis yang diajukan, yaitu :

$\mathrm{H}_{1}$ : Kualitas interaksi berpengaruh siginifikan terhadap kepuasan konsumen 


\subsubsection{Hubungan Kualitas Lingkungan Fisik dengan Kepuasan Konsumen}

Pembentukan hipotesis dimana kualitas lingkungan fisik berpengaruh siginifikan terhadap kepuasan konsumen ditentukan oleh penelitian yang dilakukan oleh Ryu dan Han (2010), mengungkapkan bahwa kualitas lingkungan fisik berpengaruh positif terhadap kepuasan konsumen. Selanjutnya, Mansor (2012) juga mengungkapkan bahwa kualitas lingkungan fisik memiliki pengaruh positif terhadap kepuasan konsumen.

Kualitas yang dirasakan dari lingkungan fisik merupakan faktor penting dalam kepuasan konsumen. ini menjadi dasar pengembangan hipotesis yang diajukan, yaitu : $\mathrm{H}_{2}$ : Kualitas lingkungan fisik berpangaruh siginifikan terhadap kepuasan konsumen.

\subsubsection{Hubungan Kualitas Hasil dengan Kepuasan Konsumen}

Pembentukan hipotesis dimana kualitas hasil berpengaruh siginifikan terhadap kepuasan konsumen ditentukan oleh penelitian yang dilakukan oleh Mansor, et al (2012), menyatakan bahwa kualitas hasil mengacu pada hasil kinerja pelayanan dan mewakili apa yang inginkan oleh konsumen dari pelayanan. Waktu tunggu, bukti fisik, dan valance adalah atribut yang memberikan kontribusi pada kepuasan konsumen. Hal ini dapat dimaknai bahwa kualitas hasil berpengaruh positif terhadap kepuasan konsumen. Ini menjadi dasar pengembangan hipotesis yang diajukan, yaitu :

$\mathrm{H}_{3}$ : Kualitas hasil berpengaruh siginifikan terhadap kepuasan konsumen

Rerangka pemikiran penelitian ini sebagai berikut :

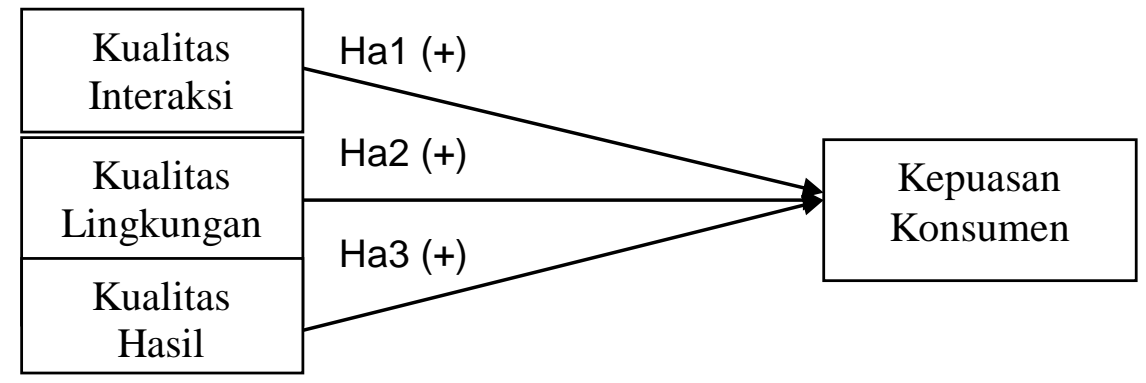

\section{Gambar 2.4. Rerangka Penelitian}

\subsection{Hipotesis Penelitian}

Adapun hipotesis untuk penelitian ini adalah:

Ho1: kualitas interaksi tidak berpengaruh terhadap kualitas jasa terhadap kepuasan mahasiswa S1 di STIE Indonesia Banking School

Ha1: kualitas interaksi berpengaruh terhadap kualitas jasa terhadap kepuasan mahasiswa S1 di STIE Indonesia Banking School

Ho2: kualitas lingkungan fisik tidak berpengaruh positif terhadap kualitas terhadap kepuasan mahasiswa S1 di STIE Indonesia Banking School

Ha2: kualitas lingkungan fisik berpengaruh positif terhadap kualitas jasa terhadap kepuasan mahasiswa S1 di STIE Indonesia Banking School

Ho3: kualitas hasil tidak berpengaruh positif terhadap kualitas jasa terhadap kepuasan mahasiswa S1 di STIE Indonesia Banking School 
Ha3: kualitas hasil berpengaruh positif terhadap kualitas jasa terhadap kepuasan mahasiswa S1 di STIE Indonesia Banking School

\section{METODOLOGI PENELITIAN}

\subsection{Objek Penelitian}

Lokasi penelitian ini adalah STIE Indonesia Banking School yang beralamat di jalan Kemang Raya no. 35 Jakarta Selatan. Objek penelitian ini adalah mahasiwa yang minimal telah kuliah selama 1 (satu) tahun berdasarkan pertimbangan bahwa mereka merasakan dan memahami serta menikmati pelayanan yang telah STIE Indonesia Banking School berikan dan masih banyak yang aktif mengikuti perkuliahan sehingga mereka telah memahami proses pelayanan yang diberikan oleh STIE Indonesia Banking School.

\subsection{Jenis Data dan Sumber Data}

Data yang digunakan merupakan data primer, dan mahasiswa menjadi responden penelitian. Responden yang disurvei adalah mahasiswa yang masih dan aktif mengikuti perkuliahan selama lebih dari 1 tahun.

Penelitian ini menggunakan pertanyaan dalam kuesioner yang disusun atas metode ServPerf (Service Performance) meliputi faktor-faktor kualitas interaksi, kualitas lingkungan fisik dari jasa, dan kualitas hasil dalam pelayanan STIE Indonesia Banking School kepada mahasiswa dengan skala pengukuran Likert. Service Perfomance diukur berdasarkan skala SERVPERF dari Brady Cronin (2001) dengan menggunakan pernyataan yang dikembangkan dari kualitas interaksi, kualitas lingkungan fisik dari jasa, dan kualitas hasil terhadap kualitas jasa.

\subsection{Tehnik Pengumpulan Data}

\section{a. Tehnik Penentuan Jumlah Sampel}

Tehnik penentuan jumlah sampel adalah dengan menggunakan rumus slovin dimana populasi diketahui adapun rumus sebagai berikut:

Rumus Slovin :

$$
n=\frac{N}{\left(N . d^{2}+1\right)}
$$

Dimana:

$\mathrm{n}$ = ukuran sampel

$\mathrm{N}=$ populasi

$\mathrm{d}=$ tingkat ketepatan (presisi) $5 \%(0,05)$

maka ukuran sampel yang didapat yaitu:

$\mathrm{N}=460, \mathrm{n}=460 /\left(460.0 .05^{2}+1\right)=213,95$ menjadi 214 kuesioner

\section{b. Metode Pengambilan Sampel}

Metode pengambilan sampel adalah dengan menggunakan non probability sampling dengan purposive sampling. 


\subsection{Metode Analisis Data}

Adapun metode analisis yang digunakan adalah:

1. Uji validitas

2. Uji realibilitas

3. Uji asumsi klasik meliputi: uji normalitas, uji heterokedastisitas, uji multikolinearitas

4. Uji partial t

5. Koefisien determinasi

\subsection{Operational Variabel}

TABEL 3.1

OPERASIONAL VARIABEL

\begin{tabular}{|c|c|c|c|}
\hline Variabel & Deskriptif & Measurement & $\begin{array}{c}\text { Statistic } \\
\text { Scale }\end{array}$ \\
\hline a. Kualitas Interaksi & $\begin{array}{l}\text { kualitas interaksi yaitu } \\
\text { kualitas yang berhubungan } \\
\text { erat dengan bagaimana } \\
\text { proses interaksi karyawan } \\
\text { penyedia layanan terhadap } \\
\text { konsumenya. } \\
\text { Gronroos (2000) }\end{array}$ & $\begin{array}{l}\text { 1. Sikap } \\
\text { KI } 1 \text { : Anda dapat } \\
\text { mengandalkan dosen \& } \\
\text { karyawan STIE IBS yang } \\
\text { ramah } \\
\text { KI } 2: \text { Sikap dosen \& } \\
\text { karyawan STIE IBS } \\
\text { menunjukkan kesediaan } \\
\text { mereka untuk membantu } \\
\text { saya } \\
\text { KI } 3 \text { Sikap dosen \& } \\
\text { karyawan STIE IBS } \\
\text { menunjukkan bahwa mereka } \\
\text { memahami kebutuhan saya } \\
\text { 2. Tingkah Laku } \\
\text { KI } 4 \text { : Saya dapat } \\
\text { mengandalkan dosen \& } \\
\text { karyawan STIE IBS dalam } \\
\text { mengambil tindakan untuk } \\
\text { memenuhi kebutuhan saya } \\
\text { KI } 5 \text { : dosen \& karyawan STIE } \\
\text { IBS merespon dengan cepat } \\
\text { kebutuhan saya } \\
\text { KI } 6 \text { Perilaku dosen \& } \\
\text { karyawan STIE IBS } \\
\text { menunjukkan kepada saya } \\
\text { bahwa mereka memahami } \\
\text { kebutuhan saya }\end{array}$ & Interval \\
\hline
\end{tabular}




\begin{tabular}{|c|c|c|}
\hline & & $\begin{array}{l}\text { 3. Keahlian } \\
\text { KI } 7 \text { : Anda dapat } \\
\text { mengandalkan dosen \& } \\
\text { karyawan STIE IBS yang } \\
\text { mengetahui pekerjaan } \\
\text { mereka. } \\
\text { KI } 8 \text { : dosen \& karyawan STIE } \\
\text { IBS mampu menjawab } \\
\text { pertanyaan saya cepat } \\
\text { KI } 9 \text { : dosen \& karyawan STIE } \\
\text { IBS memahami bahwa saya } \\
\text { mengandalkan pengetahuan } \\
\text { mereka untuk memenuhi } \\
\text { kebutuhan saya } \\
\text { Brady dan Cronin (2001) }\end{array}$ \\
\hline $\begin{array}{ll}\text { b. Kualitas } \\
\text { Lingkungan Fisik }\end{array}$ & $\begin{array}{l}\text { Kualitas lingkungan fisik } \\
\text { adalah sebuah kualitas yang } \\
\text { ada di dalam lingkungan } \\
\text { dimana proses pelayanan itu } \\
\text { terjadi. } \\
\text { Gronroos (2000) }\end{array}$ & $\begin{array}{l}\text { 1. Ambient Condition } \\
\text { KL } 1 \text { : Di STIE IBS, Anda } \\
\text { dapat mengandalkan } \\
\text { atmosphere/situasi } \\
\text { lingkungan kampus yang baik } \\
\text { KL } 2 \text { : Suasana STIE IBS } \\
\text { adalah apa yang saya cari } \\
\text { untuk sebuah kampus. } \\
\text { KL } 3: \text { STIE IBS memahami } \\
\text { bahwa atmosfer adalah } \\
\text { penting bagi saya } \\
2 . \text { Design } \\
\text { KL } 4 \text { : Tata letak kampus } \\
\text { STIE IBS } \\
\text { mengesankan bagi diri saya } \\
\text { KL } 5 \text { : Tata letak kampus } \\
\text { STIE IBS disajikan sesuai } \\
\text { dengan tujuan saya kuliah } \\
\text { KL } 6: \text { STIE IBS memahami } \\
\text { bahwa desain fasilitas penting } \\
\text { bagi saya. } \\
3 . \text { Faktor Sosial } \\
\text { KL } 7 \text { : Saya mendapatkan } \\
\text { bahwa mahasiswa STIE IBS } \\
\text { lainnya secara konsisten } \\
\text { memberikan kesan baik }\end{array}$ \\
\hline
\end{tabular}




\begin{tabular}{|c|c|c|c|}
\hline & & $\begin{array}{l}\text { terhadap pelayanan STIE } \\
\text { IBS. } \\
\text { KL } 8 \text { : Mahasiswa lainnya } \\
\text { tidak mempengaruhi } \\
\text { kemampuan dosen \& } \\
\text { karyawan STIE IBS untuk } \\
\text { memberikan pelayanan yang } \\
\text { terbaik bagi saya } \\
\text { KL } 9 \text { : STIE IBS memahami } \\
\text { bahwa mahasiswa lain } \\
\text { mempengaruhi persepsi saya } \\
\text { terhadap pelayanan STIE } \\
\text { IBS. } \\
\text { Brady dan Cronin (2001) }\end{array}$ & \\
\hline c. Kualitas Hasil & $\begin{array}{l}\text { Kualitas hasil adalah hasil } \\
\text { yang diperoleh } \\
\text { konsumen ketika proses } \\
\text { produksi (jasa) selesai } \\
\text { dilakukan. } \\
\text { Brady dan Cronin (2001) }\end{array}$ & $\begin{array}{l}\text { 1. Waktu Tunggu } \\
\text { KH } 1 \text { : Waktu tunggu di STIE } \\
\text { IBS dapat saya prediksi } \\
\text { KH } 2 \text { : STIE IBS mencoba } \\
\text { untuk menjaga waktu tunggu } \\
\text { saya seminimum mungkin } \\
\text { KH } 3 \text { : STIE IBS memahami } \\
\text { bahwa waktu tunggu adalah } \\
\text { penting bagi saya } \\
\text { 2. Bukti Fisik } \\
\text { KH } 4 \text { : Saya secara konsisten } \\
\text { senang dengan STIE IBS. } \\
\text { KH } 5 \text { : Saya suka dengan } \\
\text { STIE IBS karena memiliki } \\
\text { yang saya inginkan } \\
\text { KH } 6 \text { : STIE IBS mengetahui } \\
\text { apa yang mahasiswa cari } \\
\text { dari suatu kampus } \\
\text { 3. Valance } \\
\text { KH } 7 \text { : Ketika saya } \\
\text { meninggalkan kampus STIE } \\
\text { IBS, saya biasanya } \\
\text { merasakan bahwa saya } \\
\text { memiliki pengalaman yang } \\
\text { baik }\end{array}$ & Interval \\
\hline
\end{tabular}




\begin{tabular}{|c|c|c|c|}
\hline & & $\begin{array}{l}\text { KH } 8 \text {. Saya percaya STIE } \\
\text { IBS mencoba untuk memberi } \\
\text { saya pengalaman yang baik. } \\
\text { KH } 9 \text { : Saya percaya STIE } \\
\text { IBS tahu jenis pengalaman } \\
\text { yang diinginkan mahasiswa } \\
\text { Brady dan Cronin (2001) }\end{array}$ & \\
\hline Kepuasan Konsumen & $\begin{array}{l}\text { kepuasan sebagai evaluasi } \\
\text { konsumen terhadap barang } \\
\text { atau jasa dalam hubunganya } \\
\text { dengan apakah barang atau } \\
\text { jasa tersebut dapat } \\
\text { memenuhi kebutuhan dan } \\
\text { harapanya. } \\
\text { Zeithaml, et al (2008) }\end{array}$ & $\begin{array}{l}\text { KP } 1 \text { : Saya melakukan hal } \\
\text { yang tepat ketika saya } \\
\text { berkuliah di STIE IBS } \\
\text { KP } 2 \text { : Saya percaya bahwa } \\
\text { berkuliah di STIE IBS } \\
\text { mendapatkan pengalaman } \\
\text { yang memuaskan.I } \\
\text { KP } 3 \text { : Pilihan saya berkuliah } \\
\text { di STIE IBS adalah hal yang } \\
\text { bijaksana. Saya sangat puas } \\
\text { dengan keputusan saya } \\
\text { untuk kuliah di STIE IBS. } \\
\text { KP } 4 \text { : STIE IBS telah } \\
\text { melakukan pekerjaan yang } \\
\text { baik untuk memuaskan } \\
\text { kebutuhan saya } \\
\text { KP } 5 \text { : STIE IBS menawarkan } \\
\text { yang terbaik serta } \\
\text { memungkinkan } \\
\text { merencanakan harga yang } \\
\text { memenuhi kebutuhan saya } \\
\text { Hassan, et al (2003) }\end{array}$ & Interval \\
\hline
\end{tabular}

\section{PEMBAHASAN HASIL PENELITIAN}

\subsection{Gambaran Umum Obyek Penelitian}

Indonesia Banking School (IBS) merupakan Sekolah Tinggi Ilmu Ekonomi yang menyelenggarakan program studi Akuntansi dan Manajemen dengan konsentrasi di bidang perbankan dan keuangan pada jenjang Strata Satu (S1). IBS didirikan oleh Yayasan Pengembangan Perbankan Indonesia (YPPI), suatu yayasan yang didirikan dan dibina oleh Bank Indonesia (www.ibs.ac.id). 


\subsection{Pembahasan Hasil Penelitian}

\subsubsection{Karakteristik Responden}

1. Masa Perkuliahan

Dari 214 responden, teridentifikasi sebesar $42.5 \%$ responden berada pada tahun ke-2, $22.9 \%$ pada tahun ke-1, 20.1\% pada tahun ke-4, dan sisanya terdistribusi pada tahun ke2 dan di atas tahun ke-5 sebagaimana disajikan pada gambar 4.1.

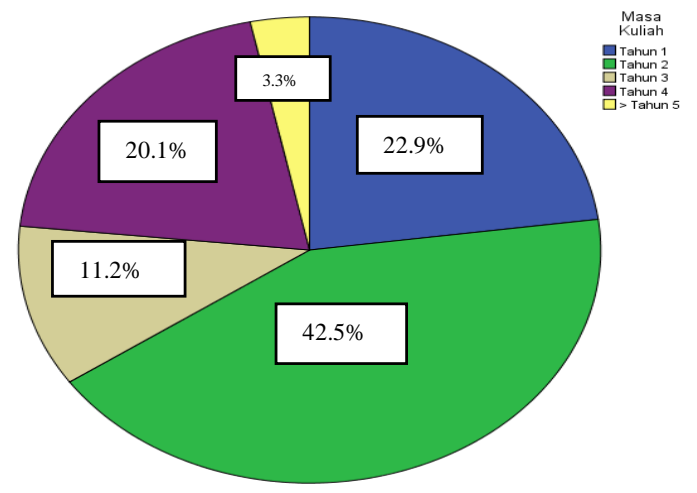

\section{Gambar 4.1. Masa Perkuliahan Responden}

2. Jenis Kelamin

Responden berjenis kelamin perempuan tampak mendominasi pada penelitian ini, sebesar $67.8 \%$ responden adalah perempuan, sisanya sebesar $32.2 \%$ laki-laki.

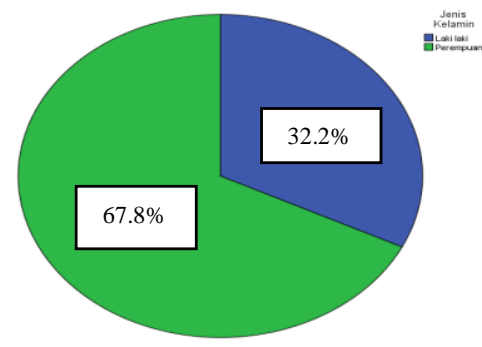

\section{Gambar 4.2. Jenis Kelamin Responden}

3. Pengeluaran per Bulan

Pengeluaran per bulan responden, mayoritas sebesar $37.4 \%$ berkisar antara $\mathrm{Rp}$. 1.000.000 - Rp. 1.900.000, 30.4\% berkisar antara Rp. 500.000 - Rp. 990.000. Sisanya terdistribusi sebagaimana tersaji pada gambar 4.3. 


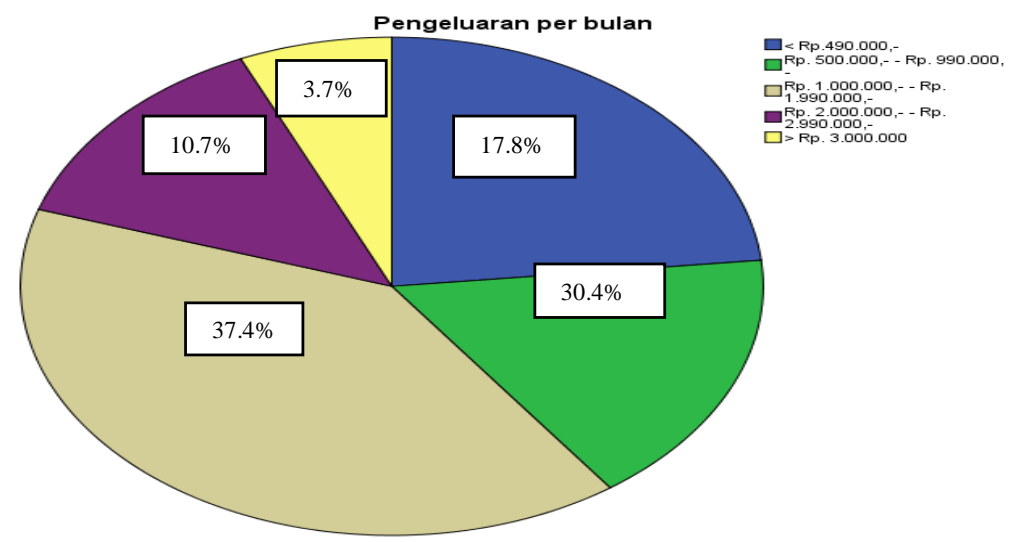

Gambar 4.3. Pengeluaran per Bulan Responden

\subsubsection{Analisis Hasil Pre-Test}

Penelitian ini dilakukan dari bulan, proses pengumpulan data dilakukan diantara rentang waktu penelitian tersebut dengan mengumpulkan responden yang berjumlah 30 orang. Selanjutnya akan dibahas mengenai uji validitas dan uji reabilitas dari data pre-test.

\subsubsection{Uji Validitas}

Berdasarkan perhitungan hasil pre-test, maka variabel dapat dikatakan valid apabila memiliki nilai Kaiser-Meyer-Olkin Measure of Sampling Adequacy (KMO) dan nilai muatan faktor (Factor Loading) diatas 0.50.

Berdasarkan uji validitas yang dilakukan terlihat bahwa semua indikator memiliki nilai KMO dan muatan faktor (factor loading) diatas 0,5 . Ini berarti pertanyaan-pertanyaan yang ada pada kuisioner mampu untuk mengungkapkan sesuatu yang akan diukur oleh kuisioner tersebut dan dengan kata lain seluruh pertanyaan sudah valid.

\subsubsection{Uji Reabilitas}

Suatu variabel pengukuran dapat dikatakan reliabel jika nilai alpha lebih besar dari $r$ kritis product moment. Reliabilitas kurang dari 0.6 adalah kurang baik, sedangkan 0.7 dapat diterima dan di atas 0.8 adalah baik.

Berdasarkan hasil pengujian dapat diketahui bahwa seluruh variabel penelitian memiliki nilai cronbach's alpha diatas 0,6, yang artinya seluruh jawaban responden terhadap pertanyaanpertanyaan yang ada di dalam kuisioner untuk mengukur variabel yang ada adalah konsisten atau stabil dari waktu ke waktu sehingga variabel dapat diandalkan (reliable).

\subsubsection{Analisis Hasil Data Penelitian}

Proses pengumpulan data dilakukan dengan terlebih dahulu mengumpulkan responden sebanyak 30 orang untuk melakukan pre-test. Setelah melakukan pre-test maka peneliti kembali mengumpulkan sisa responden yang dibutuhkan yaitu sebanyak 184 orang karena sampel yang ingin diambil berjumlah 214 orang. 


\subsubsection{Uji validitas}

Berdasarkan perhitungan hasil main-test, maka variabel dapat dikatakan valid apabila memiliki nilai Kaiser-Meyer-Olkin Measure of Sampling Adequacy (KMO) dan nilai muatan faktor (Factor Loading) diatas 0,50. Hasil pengujian validitas akan digambarkan pada tabel berikut ini.

Tabel 4.1. Hasil pengujian validitas main test

\begin{tabular}{|c|c|c|c|c|}
\hline Variabel & Indikator & KMO & $\begin{array}{l}\text { Faktor } \\
\text { Loading }\end{array}$ & Kesimpulan \\
\hline \multirow[t]{9}{*}{$\begin{array}{l}\text { Kualitas } \\
\text { Interaksi }\end{array}$} & $\begin{array}{l}\text { Anda dapat mengandalkan } \\
\text { karyawan STIE IBS yang } \\
\text { ramah }\end{array}$ & \multirow[t]{9}{*}{0.939} & 0.955 & Valid \\
\hline & 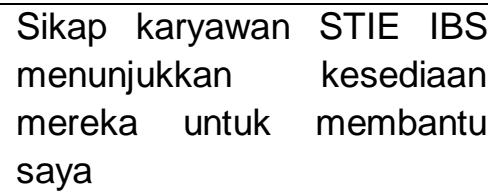 & & 0.941 & Valid \\
\hline & $\begin{array}{l}\text { Sikap karyawan STIE IBS } \\
\text { menunjukkan bahwa mereka } \\
\text { memahami kebutuhan saya }\end{array}$ & & 0.955 & Valid \\
\hline & $\begin{array}{l}\text { Saya dapat mengandalkan } \\
\text { karyawan STIE IBS dalam } \\
\text { mengambil tindakan untuk } \\
\text { memenuhi kebutuhan saya }\end{array}$ & & 0.949 & Valid \\
\hline & $\begin{array}{l}\text { Karyawan STIE IBS } \\
\text { merespon dengan cepat } \\
\text { kebutuhan saya. }\end{array}$ & & 0.917 & Valid \\
\hline & $\begin{array}{l}\text { Perilaku karyawan STIE IBS } \\
\text { menunjukkan kepada saya } \\
\text { bahwa mereka memahami } \\
\text { kebutuhan saya }\end{array}$ & & 0.908 & Valid \\
\hline & $\begin{array}{l}\text { Anda dapat mengandalkan } \\
\text { karyawan STIE IBS yang } \\
\text { mengetahui } \\
\begin{array}{ll}\text { mereka } & \text { pekerjaan }\end{array}\end{array}$ & & 0.941 & Valid \\
\hline & $\begin{array}{l}\text { Karyawan STIE IBS mampu } \\
\text { menjawab pertanyaan saya } \\
\text { dengan cepat }\end{array}$ & & 0.954 & Valid \\
\hline & $\begin{array}{l}\text { Karyawan STIE IBS } \\
\text { memahami bahwa saya } \\
\text { mengandalkan pengetahuan } \\
\text { mereka untuk memenuhi } \\
\text { kebutuhan saya }\end{array}$ & & 0.944 & Valid \\
\hline $\begin{array}{l}\text { Kualitas } \\
\text { Lingkungan } \\
\text { Fisik }\end{array}$ & $\begin{array}{l}\text { Di STIE IBS, Anda dapat } \\
\text { mengandalkan } \\
\text { atmosphere/situasi } \\
\text { lingkungan kampus yang } \\
\text { baik }\end{array}$ & 0.848 & 0.888 & Valid \\
\hline
\end{tabular}




\begin{tabular}{|c|c|c|c|c|}
\hline & $\begin{array}{l}\text { Suasana STIE IBS adalah } \\
\text { apa yang saya cari untuk } \\
\text { sebuah kampus. }\end{array}$ & & 0.879 & Valid \\
\hline & $\begin{array}{l}\text { STIE IBS memahami bahwa } \\
\text { atmosfer adalah penting bagi } \\
\text { saya }\end{array}$ & & 0.836 & Valid \\
\hline & $\begin{array}{l}\text { Tata letak kampus STIE IBS } \\
\text { sangat mengesankan bagi } \\
\text { diri saya }\end{array}$ & & 0.743 & Valid \\
\hline & $\begin{array}{l}\text { Tata letak kampus } \\
\text { disajikan sesuai } \\
\text { tujuan saya kuliah. }\end{array}$ & & 0.774 & Valid \\
\hline & $\begin{array}{l}\text { STIE IBS memahami bahwa } \\
\text { desain fasilitas penting bagi } \\
\text { saya. }\end{array}$ & & 0.882 & Valid \\
\hline & $\begin{array}{l}\text { Saya mendapatkan bahwa } \\
\text { mahasiswa STIE IBS lainnya } \\
\text { secara konsisten } \\
\text { memberikan kesan baik } \\
\text { terhadap pelayanan STIE } \\
\text { IBS. }\end{array}$ & & 0.870 & Valid \\
\hline & $\begin{array}{l}\text { Mahasiswa lainnya tidak } \\
\text { mempengaruhi kemampuan } \\
\text { dosen \& karyawan STIE IBS } \\
\text { untuk memberikan } \\
\text { pelayanan yang terbaik bagi } \\
\text { saya }\end{array}$ & & 0.924 & Valid \\
\hline & \begin{tabular}{lr}
\multicolumn{2}{l}{ STIE IBS memahami bahwa } \\
mahasiswa & lain \\
mempengaruhi & persepsi \\
saya terhadap & pelayanan \\
STIE IBS. &
\end{tabular} & & 0.940 & Valid \\
\hline \multirow[t]{5}{*}{ Kualitas Hasil } & $\begin{array}{l}\text { Waktu tunggu di STIE IBS } \\
\text { dapat saya prediksi }\end{array}$ & \multirow[t]{5}{*}{0.883} & 0.807 & Valid \\
\hline & $\begin{array}{l}\text { STIE IBS mencoba untuk } \\
\text { menjaga waktu tunggu saya } \\
\text { seminimum mungkin }\end{array}$ & & 0.869 & Valid \\
\hline & $\begin{array}{l}\text { STIE IBS memahami bahwa } \\
\text { waktu tunggu adalah penting } \\
\text { bagi saya }\end{array}$ & & 0.848 & Valid \\
\hline & $\begin{array}{l}\text { Saya secara konsisten } \\
\text { senang dengan STIE IBS. }\end{array}$ & & 0.953 & Valid \\
\hline & $\begin{array}{l}\text { Saya suka dengan STIE IBS } \\
\text { karena memiliki yang saya } \\
\text { inginkan }\end{array}$ & & 0.873 & Valid \\
\hline
\end{tabular}




\begin{tabular}{|c|c|c|c|c|}
\hline & $\begin{array}{l}\text { STIE IBS mengetahui apa } \\
\text { yang mahasiswa cari dari } \\
\text { suatu kampus }\end{array}$ & & 0.869 & Valid \\
\hline & $\begin{array}{l}\text { Ketika saya meninggalkan } \\
\text { kampus STIE IBS, saya } \\
\text { biasanya merasakan bahwa } \\
\text { saya memiliki pengalaman } \\
\text { yang baik }\end{array}$ & & 0.924 & Valid \\
\hline & $\begin{array}{l}\text { Saya percaya STIE IBS } \\
\text { mencoba untuk memberi } \\
\text { saya pengalaman yang baik. }\end{array}$ & & 0.874 & Valid \\
\hline & $\begin{array}{l}\text { Saya percaya STIE IBS tahu } \\
\text { jenis pengalaman yang } \\
\text { diinginkan mahasiswa }\end{array}$ & & 0.896 & Valid \\
\hline \multirow[t]{5}{*}{$\frac{\text { Kepuasan }}{\text { Konsumen }}$} & $\begin{array}{l}\text { Saya melakukan hal yang } \\
\text { tepat ketika saya berkuliah di } \\
\text { STIE IBS. }\end{array}$ & \multirow[t]{5}{*}{0.877} & 0.912 & Valid \\
\hline & $\begin{array}{l}\text { Saya percaya bahwa } \\
\text { berkuliah di STIE IBS } \\
\text { mendapatkan pengalaman } \\
\text { yang memuaskan. }\end{array}$ & & 0.861 & Valid \\
\hline & $\begin{array}{l}\text { Pilihan saya berkuliah di } \\
\text { STIE IBS adalah hal yang } \\
\text { bijaksana. Saya sangat puas } \\
\text { dengan keputusan saya } \\
\text { untuk kuliah di STIE IBS. }\end{array}$ & & 0.844 & Valid \\
\hline & $\begin{array}{l}\text { STIE IBS telah melakukan } \\
\text { pekerjaan yang baik untuk } \\
\text { memuaskan kebutuhan saya }\end{array}$ & & 0.879 & Valid \\
\hline & $\begin{array}{l}\text { STIE IBS menawarkan yang } \\
\text { terbaik serta memungkinkan } \\
\text { merencanakan harga yang } \\
\text { memenuhi kebutuhan saya. }\end{array}$ & & 0.912 & Valid \\
\hline
\end{tabular}

Sumber : Data kuisioner diolah

Setelah dilakukan pengumpulan data maka dapat diketahui bahwa semua nilai KMO dan factor loading dari indikator yang ada berada diatas 0,5 . Ini berarti pertanyaan-pertanyaan yang ada pada kuisioner mampu untuk mengungkapkan sesuatu yang akan diukur oleh kuisioner tersebut dan dengan kata lain seluruh pertanyaan sudah valid.

\subsubsection{Uji Reabilitas}

Suatu variabel pengukuran dapat dikatakan reliabel jika nilai alpha lebih besar dari $r$ kritis product moment. Reliabilitas kurang dari 0.6 adalah kurang baik, sedangkan 0.7 dapat diterima dan di atas 0.8 adalah baik. Hasil pengujian reabilitas akan digambarkan pada tabel berikut ini : 
Tabel 4.2. Hasil pengujian reabilitas main test

\begin{tabular}{|l|c|c|l|}
\hline \multicolumn{1}{|c|}{ Variabel } & $\begin{array}{c}\text { Jumlah } \\
\text { pertanyaan }\end{array}$ & Cronbach's Alpha & \multicolumn{1}{|c|}{ Kesimpulan } \\
\hline Kualitas Interaksi & 9 & 0.943 & Reliabel \\
\hline $\begin{array}{l}\text { Kualitas Lingkungan } \\
\text { Fisik }\end{array}$ & 9 & 0.866 & Reliabel \\
\hline Kualitas Hasil & 9 & 0.909 & Reliabel \\
\hline Kepuasan Konsumen & 5 & 0.897 & Reliabel \\
\hline
\end{tabular}

Sumber : Data kuisioner diolah

Berdasarkan hasil uji reabilitas pada tabel 4.12 dapat kita ketahui bahwa semua dimensi yang ada memiliki cronbach's alpha diatas 0,6 . Ini berarti seluruh jawaban responden terhadap pertanyaan-pertanyaan yang ada di dalam kuisioner untuk mengukur variabel yang ada adalah konsisten atau stabil dari waktu ke waktu sehingga variabel dapat diandalkan (reliable).

\subsubsection{Uji Asumsi Klasik}

Terdapat empat asumsi yang terpenting sebagai syarat penggunaan metode regresi, yakni normalitas, multikolinearitas, autokorelasi, dan heteroskedasitas. Pengujian ini diperlukan karena adanya konsekuensi yang mungkin terjadi jika asumsi tersebut tidak terpenuhi. Dibawah ini penjelasan dari asumsi klasik tersebut:

\subsubsection{Uji Normalitas}

Uji normalitas bertujuan untuk menguji apakah dalam model regresi variabel dependen dan variabel independen terdistribusi secara normal atau tidak. Dalam pengujian menggunakan analisis statistik digunakan uji statistik non parametrik Kolmogorov-Smornov (K-S). Untuk menentukan normalitas data ditentukan dengan ketentuan jika signifikansi K-S statistik > 0,05 maka data terdistribusi normal. Uji K-S ini dilakukan dengan membuat hipotesis :

$\mathrm{HO}$ : Data residual berdistribusi normal

$\mathrm{Ha}$ : Data residual tidak berdistribusi normal

Dibawah ini merupakan hasil pengujian dengan menggunakan uji statistik non parametrik Kolmogorov-Smirnov (K-S):

Tabel 4.3. Pengujian normalitas Kolmogorov-Smirnov test - One Sample KolmogorovSmirnov Test

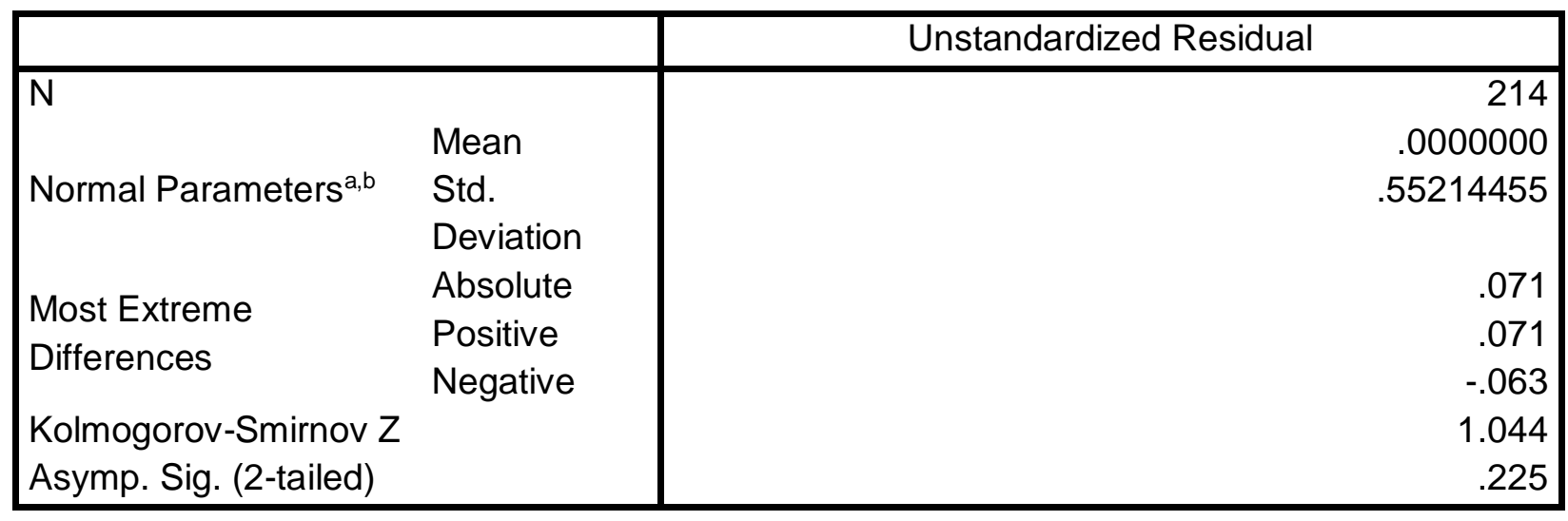


Dari hasil pengujian normalitas menggunakan teknik non parametrik Kolmogorov-Smirnov (K-S) dengan nilai unstandardized residual didapatkan nilai Asymp. Sig. sebesar 0,225. Ketentuan data dikatakan normal bila nilai Asymp. Sig. lebih besar dari 0,05, dengan kata lain pada penelitian ini data terdistribusi secara normal dikarenakan memiliki nilai Asymp. Sig. lebih besar dari 0,05 yaitu 0,225 .

\subsubsection{Uji Heteroskedastisitas}

Uji heteroskedastisitas bertujuan untuk menguji apakah dalam model regresi terjadi ketidaksamaan varians dari residual satu pengamatan ke pengamatan yang lain. Dalam hal ini penulis melihat pola titik-titik pada scatter plots regresi. metodenya adalah dengan membuat grafik plot atau scatter antara "Standardized Predicted Value (ZPRED)" dengan "Studentized Residual (SRESID)". Ada tidaknya pola tertentu pada grafik scatterplot antara SRESID dan ZPRED adalah sumbu $Y$ dimana sumbu $Y$ yang telah diprediksi dan Sumbu $X$ adalah Residual (Y Prediksi - Y Sesungguhnya).

Adapun kriteria pengujian untuk menjawab hipotesisnya adalah seperti di bawah ini:

1. Ho: Tidak ada gejala heteroskedastisitas apabila tidak ada pola yang jelas, seperti titiktitik menyebar di atas dan di bawah angka 0 pada sumbu $Y$.

2. Ha: Ada gejala heteroskedastisitas apabila ada pola tertentu yang jelas, seperti titik-titik membentuk pola tertentu yang teratur (bergelombang, melebar kemudian menyempit).

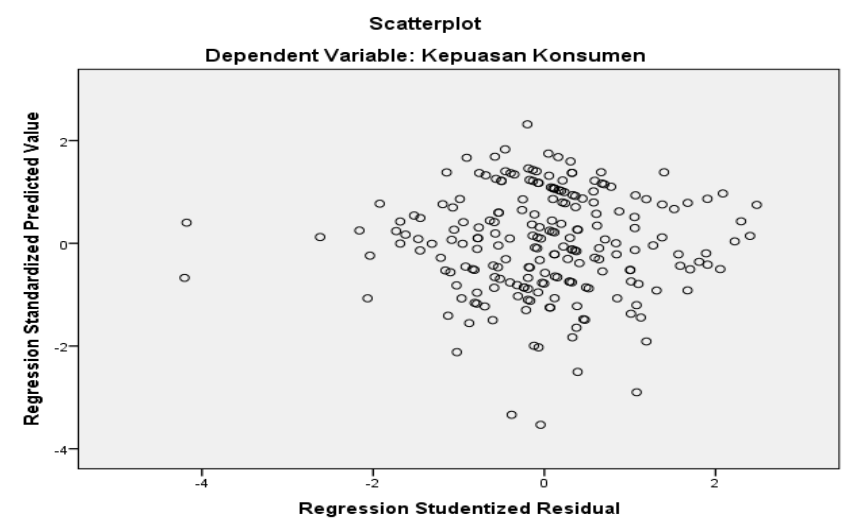

Gambar 4.4. Uji Heteroskedastisitas

Pada Grafik Scatter, jelas bahwa tidak ada pola tertentu karena titik meyebar tidak beraturan di atas dan di bawah sumbu 0 pada sumbu Y. Maka dapat disimpulkan tidak terdapat gejala heteroskedastisitas atau $\mathrm{HO}$ diterima.

\subsubsection{Uji Muktikolinearitas}

Uji multikolinearitas bertujuan untuk menguji apakah model regresi ditemukan adanya korelasi antar variabel bebas (independen). Model regresi yang baik seharusnya tidak terjadi korelasi diantara variabel independen. Untuk mengetahui apakah ada gejala multikolinearitas atau tidak terdapat dua cara yaitu dengan melihat korelasi antar variabelnya pada tabel coefficient correlations dan dengan melihat nilai Variance Inflation Factor (VIF) dari tabel coliniearity statistic. Dalam Ghozali (2009) agar tidak terjadi gejala multikolinearitas maka korelasi antar variabel haruslah dibawah 95\% dan nilai dari VIF haruslah dibawah 10, jika suatu variabel memenuhi hal 
tersebut maka dapat disimpulkan bahwa tidak terjadi gejala multikolinearitas. Berikut adalah hasil dari uji multikolinearitas tersebut :

\section{Tabel 4.4. Hasil korelasi uji multikolinearitas \\ Coefficients $^{a}$}

\begin{tabular}{|c|c|c|c|c|c|c|c|}
\hline \multirow[t]{2}{*}{ Model } & \multicolumn{2}{|c|}{$\begin{array}{l}\text { Unstandardized } \\
\text { Coefficients }\end{array}$} & \multirow{2}{*}{$\begin{array}{c}\begin{array}{c}\text { Standardiz } \\
\text { ed } \\
\text { Coefficients }\end{array} \\
\text { Beta }\end{array}$} & \multirow[t]{2}{*}{$t$} & \multirow[t]{2}{*}{ Sig. } & \multicolumn{2}{|c|}{$\begin{array}{l}\text { Collinearity } \\
\text { Statistics }\end{array}$} \\
\hline & $B$ & $\begin{array}{l}\text { Std. } \\
\text { Error }\end{array}$ & & & & $\begin{array}{c}\text { Toleranc } \\
\mathrm{e}\end{array}$ & VIF \\
\hline (Constant) & .155 & .218 & & .711 & .478 & & \\
\hline Kualitas Interaksi & .051 & .045 & .048 & 1.120 & .264 & .661 & 1.513 \\
\hline $\begin{array}{l}\text { Kualitas Lingkungan } \\
\text { Fisik }\end{array}$ & .164 & .061 & .146 & 2.686 & .008 & .417 & 2.401 \\
\hline Kualitas Hasil & .780 & .061 & .717 & 12.735 & .000 & .387 & 2.587 \\
\hline
\end{tabular}

Sumber : Data kuisioner diolah

Berdasarkan tabel diatas dapat kita ketahui bahwa nilai VIF untuk kualitas interaksi kurang dari 10 yaitu 1,513 dan juga nilai VIF untuk kualitas lingkungan fisik juga kurang dari 10 yaitu 2,401, serta nilai VIF untuk Kualitas hasil yaitu 2.587 juga kurang dari 10. Dari nilai VIF seluruh variabel yang ada maka dapat disimpulkan bahwa tidak terjadi gejala multikolinearitas.

\subsubsection{Pengujian Hipotesis}

\subsubsection{Uji t}

Uji ini digunakan untuk mengetahui apakah dalam model regresi variabel independen secara parsial berpengaruh signifikan terhadap variabel dependen, yaitu untuk mengetahui pengaruh variabel Kualitas Interaksi terhadap Kepuasan Konsumen, pengaruh Kualitas Lingkungan Fisik terhadap Kepuasan Konsumen dan pengaruh Kualitas Hasil terhadap Kepuasan Konsumen. Jika $p \geq 0,05$ maka tidak terdapat hubungan yang signifikan. Berikut adalah hasil dari uji t penelitian ini :

Tabel 4.5. Hasil uji t

Coefficients $^{a}$

\begin{tabular}{|c|c|c|c|c|c|c|}
\hline \multirow{2}{*}{\multicolumn{2}{|c|}{ Model }} & \multicolumn{2}{|c|}{$\begin{array}{c}\text { Unstandardized } \\
\text { Coefficients }\end{array}$} & \multirow{2}{*}{$\begin{array}{c}\begin{array}{c}\text { Standardized } \\
\text { Coefficients }\end{array} \\
\text { Beta }\end{array}$} & \multirow[t]{2}{*}{$\mathrm{t}$} & \multirow[t]{2}{*}{ Sig. } \\
\hline & & $B$ & Std. Error & & & \\
\hline \multirow{4}{*}{1} & (Constant) & .155 & .218 & & .711 & .478 \\
\hline & Kualitas Interaksi & .051 & .045 & .048 & 1.120 & .264 \\
\hline & $\begin{array}{l}\text { Kualitas Lingkungan } \\
\text { Fisik }\end{array}$ & .164 & .061 & .146 & 2.686 & .008 \\
\hline & Kualitas Hasil & .780 & .061 & .717 & 12.735 & .000 \\
\hline
\end{tabular}

a. Dependent Variable: Kepuasan Konsumen 
Berdasarkan tabel diatas dapat kita lihat bahwa nilai Sig. untuk variabel Kualitas Interaksi adalah $0.264 \geq 0.05$, yang berarti variabel Kualitas Interaksi tidak memiliki pengaruh yang signifikan terhadap Kepuasan Konsumen sehingga $\mathrm{HO}$ diterima. Kemudian nilai Sig. untuk variabel Kualitas Lingkungan Fisik sebesar $0.008 \leq 0,05$, yang berarti variabel Kualitas Lingkungan Fisik memiliki pengaruh yang signifikan terhadap Kepuasan Konsumen sehingga $\mathrm{HO}$ ditolak. Selanjutnya nilai Sig untuk variabel Kualitas Hasil $0.000<0.05$, yang berarti variabel Kualitas hasil memiliki pengaruh yang signifikan terhadap Kepuasan konsumen sehingga $\mathrm{H} 0$ diterima.

Dengan menggunakan skala yang sama untuk setiap pertanyaan yang diajukan maka dapat dilihat variabel mana yang lebih dominan dengan menggunakan standardized coefficients beta pada tabel. Dari tabel tersebut dapat dilihat bahwa nilai standardized coefficients beta untuk variabel Kualitas Hasil lebih besar dibandingkan dengan variabel Kualitas Lingkungan Fisik yaitu sebesar 0,780. Hal ini berarti variabel Kualitas Hasil merupakan variabel yang lebih dominan dibandingkan dengan Kualitas Lingkungan Fisik dalam mempengaruhi kepuasan konsumen sebagai variabel dependen.

\subsubsection{Pembahasan Model Persamaan Regresi}

$\mathrm{KK}=$ Kepuasan Konsumen

$$
\mathrm{KK}=0,155+0.051 \mathrm{KI}+0.164 \mathrm{KLF}+0.780 \mathrm{KH}
$$

$\mathrm{KI} \quad=$ Kualitas Interaksi

$\mathrm{KLF} \quad=$ Kualitas Lingkungan Fisik

$\mathrm{KH} \quad=$ Kualitas Hasil

Koefisien regresi $\mathrm{KI}$ sebesar 0.051 bertanda positif menyatakan bahwa variabel $\mathrm{KI}$ berbanding lurus dengan tingkat KK. Kemudian untuk koefisien regresi KLF sebesar 0.164 bertanda positif menyatakan bahwa variabel KLF juga berbanding lurus dengan tingkat KK. Selanjutnya koefisien regresi $\mathrm{KH}$ sebesar 0.780 bertanda positif menyatakan bahwa variabel $\mathrm{KH}$ juga berbanding lurus dengan tingkat KK.

Konstanta yang sebesar 0,155 bertanda positif memiliki arti bahwa jika tidak ada KI, KLF dan $\mathrm{KH}$ maka nilai KK sebesar 0,105. Selanjutnya, koefisien regresi KI sebesar 0.051 menyatakan bahwa setiap penambahan satu satuan akan meningkatkan kepuasan konsumen sebesar 0.051 .

\subsubsection{Koefisien Determinasi (Adjusted $\mathbf{R}^{2}$ )}

Tabel 4.6. Hasil Koefisien Determinasi Model Summary

\begin{tabular}{|c|c|c|c|c|}
\hline Model & $\mathrm{R}$ & $\mathrm{R}$ Square & $\begin{array}{c}\text { Adjusted R } \\
\text { Square }\end{array}$ & $\begin{array}{c}\text { Std. Error of } \\
\text { the Estimate }\end{array}$ \\
\hline 1 &, $862^{\mathrm{a}}$ &, 743 &, 739 &, 55607 \\
\hline
\end{tabular}

a. Predictors: (Constant), Kualitas Hasil, Kualitas

Interaksi, Kualitas Lingkungan Fisik

Sumber : Data kuesioner diolah 
Analisis koefisien deteminasi $\left(R^{2}\right)$ digunakan untuk menguji sejauh mana variasi variabel independen mampu menjelaskan variabel dependen. Nilai yang digunakan adalah Adjusted $R$ Square sebagai koefisien determinasi adalah hasil perhitungan $\mathrm{R}^{2}$, dapat dilihat dari tabel diatas dapat kita ketahui bahwa adjusted $\mathrm{R}^{2}$ sebesar 0,739 . Hal ini berarti variabel independen yaitu Kualitas Hasil, Kualitas Interaksi dan Kualitas Lingkungan Fisik memiliki pengaruh sebesar 73,90 \% terhadap Kepuasan Konsumen, sisanya sebesar 26,1 \% dipengaruhi oleh faktor lain yang tidak diteliti dalam penelitian ini.

\subsubsection{Implikasi Manajerial}

Variabel dominan dalam penelitian ini adalah Kualitas Hasil dengan indikator-indikator : STIE IBS mencoba untuk menjaga waktu tunggu saya seminimum mungkin, waktu tunggu di STIE IBS dapat saya prediksi, saya suka dengan STIE IBS karena memiliki yang saya inginkan dan STIE IBS mengetahui apa yang mahasiswa cari dari suatu kampus. Keempat indikator tersebut dapat dikelompokkan menjadi 2 (dua) hal penting yang akan dibahas yaitu : waktu tunggu yang dapat diprediksi serta seminimum mungkin serta pengetahuan keinginan dan kebutuhan mahasiswa terhadap suatu kampus sehingga dapat menimbulkan kesukaan mahasiswa terhadap kampus.

Permasalahan waktu tunggu dapat ditingkatkan kepastian serta diprediksi penyelesaian pelayanannya apabila STIE Indonesia Banking School dapat menetapkan standar waktu pelayanan untuk pelayanan mahasiswa khususnya dalam pelayanan akademik. Standar ini dapat menjadi acuan bagi staf atau karyawan dalam melayani mahasiswa sehingga mahasiswa sebagai konsumen STIE Indonesia Banking School dapat memprediksi pelayanan kepada mereka. Penerapan standar ini bisa dilakukan dengan melakukan studi banding dengan kampus-kampus lama yang memiliki jumlah mahasiswa besar. Selain itu bagian SDM dan pelayanan mahasiswa melakukan pemetaan kinerja dan kompetensi bagian pelayanan untuk melihat apakah masih bisa ditingkatkan atau perlu menambah SDM agar pelayanannya lebih cepat dan akurat. Setelah dilakukan standarisasi dan analisis kinerja maka langkah selanjutnya menginformasikan standar pelayanan kepada staf dan mahasiswa agar mereka dapat memprediksi waktu pelayanan.

Pengetahuan keinginan dan kebutuhan mahasiswa terhadap suatu kampus yang berdampak menimbulkan kesukaan mahasiswa terhadap kampus dapat dilakukan oleh STIE Indonesia Banking School (IBS) dengan mengadakan survey secara periodik melalui system informasi dengan mendetailkan pertanyaan mengenai kebutuhan mahasiswa terhadap suatu kampus. Hasil survey ini ditindaklanjuti secara prioritas berdasarkan kepentingan dan kemampuan STIE IBS. Penginformasian mengenai hal-hal yang akan dilakukan STIE IBS dalam memenuhi keinginan dan kebutuhan mahasiswa hendaknya disampaikan kepada mahasiswa agar mahasiswa dapat turut membantu dan mengawal pelaksanaannya dengan baik dan akhirnya akan menimbulkan kesukaan mahasiswa terhadap kampusnya.

\section{KESIMPULAN DAN SARAN}

\subsection{Kesimpulan}

Berdasarkan kajian terhadap teori-teori yang berkaitan dengan penelitian serta melakukan analisis data pada bab-bab sebelumnya, peneliti mendapatkan kesimpulan sebagai berikut. 
1. Tidak terdapat pengaruh kualitas jasa interaksi terhadap kepuasan mahasiswa S1 di STIE Indonesia Banking School.

2. Terdapat Pengaruh kualitas lingkungan jasa terhadap kepuasan mahasiswa S1 di STIE Indonesia Banking School .

3. Terdapat Pengaruh kualitas hasil terhadap kepuasan mahasiswa S1 di STIE Indonesia Banking School.

4. Ditemukan pengaruh kualitas hasil yang paling dominan diantara pengaruh kualitas jasa interaksi, lingkungan jasa dan hasil terhadap kepuasan mahasiswa S1 di STIE Indonesia Banking School

\subsection{Saran}

Pengembangan implikasi manajerial secara spesifik yang melihat indikator-indikator terendah dalam variabel-variabel yang mempengaruhi khususnya variabel yang dominan yaitu Kualitas Hasil menghasilkan beberapa saran yang dapat dilakukan oleh STIE IBS yaitu :

1. Melakukan studi banding dengan kampus-kampus yang baik dalam pelayanan mahasiswa dilihat dari eksistensi kampus tersebut dalam dunia pendidikan dan jumlah mahasiswanya yang besar/banyak.

2. Melakukan analisis kinerja dan kompetensi dari bagian pelayanan kepada mahasiswa seperti bagian akademik/jurusan, keuangan, kemahasiswaan, serta bagian lain yang secara langsung melayani mahasiswa.

3. Menyusun standar waktu dan hasil dari pelayanan kepada mahasiswa berdasarkan hasil studi banding dan analisis kinerja dan kompetensi.

4. Melakukan survey kebutuhan dan keinginan mahasiswa terhadap kampus secara periodik agar dapat terpantau perkembangan tuntutan mahasiswa terhadap kampus yang ideal sebagai tempat pendidikan tinggi.

5. Mensosialisasikan hasil standar waktu dan hasil serta prioritas tindakan pemenuhan kebutuhan dan keinginan mahasiswa kepada mahasiswa agar nantinya mahasiswa mengetahui bahwa STIE IBS memiliki keperdulian terhadap mahasiswa sehingga akhirnya membuat mereka suka akan kampus ini.

Penelitian ini selain bermanfaat bagi STIE Indonesia Banking School juga dapat menjadi dasar penelitian serupa yang dapat dilakukan di kampus-kampus lain. Selain itu para peneliti selanjutnya dapat menambahkan variabel-variabel lain yang dapat mempengaruhi kepuasan konsumen (mahasiswa) disesuaikan dengan kondisi kampusnya dan kebutuhan hasil penelitian kampus tersebut.

\section{DAFTAR PUSTAKA}

Assael, Henry. (2001). Consumer Behaviour 6th Edition. New York. Thompson Learning.

Brady, Michael K., Cronin, J. Joseph Jr. (2001) Some New Thoughts on Conceptualizing Perceived Service Quality: A Hierarchical Approach. Journal of Marketing: July 2001, Vol. 65, No. 3, pp. 34-49.

Boone L. E. and Kurtz D. L. (2007), Contemporary Marketing, Harcourt College Publishers, Philadelphia. 
Cronin, J.J dan Taylor, S.A. [1994], SERVPERF versus SERVQUAL : Reconciling Performance Based and Perception Minus Expectations Measurement of Service Quality, Journal of Marketing.

Gerson, Richard F. (1993). Measuring Customer Satisfaction. A Crisp Fifty-Minute Series Book. Thompson Place. Course Technology.

Grönroos, C. (2000). Service Management and Marketing. A Customer Relationship Management Approach. Chichester: John Wiley.

Gronroos, Michael. (2007). Service Management and Marketing: Customer Management in Service Competition. 3th Edition. Wiley Publisher.

Hassan, H. A., Tamimi, A., and Al-Amiri, A. (2003). Analysing service quality in the UAE Islamic banks. Journal of Financial Services Marketing, 8(2), 119-132.

K, Ryu and H. Han.(2010). Influence of the Quality of Food, Service, and Physical Environment on Customer Satisfaction and Behavioral Intention in Quick-Casual Restaurant: Moderating Role of Perceived Price, Journal of Hospitality \& Tourism Research, vol. 34.

Kotler, P., and Armstrong, G. (2010). Principles of Marketing, 13th Ed. New Jersey: Pearson Education, Inc.

Kotler, Philip and Armstrong, Gary. (2006). Principles of Marketing. Pearson Prentice Hall.

Kotler, Philip and Keller, Kevin Lane. (2006). Marketing Management 12th Edition. Prentice Hall.

Lockhart, J.M. 2005. How to Market Your School: A Guide to Marketing, Public Relation, and

Communication for School Administrators. luniverse, Inc.

Lovelock, Christopher and Wirzt, Jochen. (2011). Service Marketing: People, Technology, Strategy. 7th Edition. Pearson Education.

Mansor, Aida Azlina., Rahayu H., and M.Hafiz (2012) Hierarhical Service Quality Model Toward Student Satisfaction. International Journal of Innovation, Management and Technology. Vol. 3, No. 6, December 2012

Teas, R. Kenneth [1994], Expectations, Performances, Evaluation, and Consumers Perception of Quality, Journal of Marketing. Vol. 57, Oktober.

Tessema, Mussie T., Ready, Kathryn and Yu, Wei-Choun "William. (2012). Factors Affecting Collage Students' Satidfaction with Major Curriculum: Evidence from Nine Years of Data. International Journal and Humanities and Social Science. Vol. 2 No. 2. Special Issue

Wijaya, David. 2012. Pemasaran Jasa Pendidikan "Mengapa Sekolah Memerlukan Marketing?". Jakarta: Salemba Empat.

Zeithaml, V. A., Mary, B., \& Dwayne, G. (2008). Service Marketing (5th ed.). 